\title{
IMPLEMENTATION OF NON-DISCRIMINATION IN RESPECT TO DETERMINE THE APPROPRIATE POLICY FOR DEALING WITH INTERNATIONAL TRADE
}

\author{
Dijan Widijowati \\ Jayabaya University, Jakarta, Indonesia \\ Email: turiz_diyan00@yahoo.com
}

Abstract: International trade is an activity involving the exchange of goods and services across national borders. International trade is strongly influenced by the harmonization of political, legal, social and cultural rights owned by respective countries. A number of principles have been formulated and enforced to prevent and resolve disputes arising from international trade, one of which is the principle of non-discrimination. In practice the existence of the principle of non-discrimination often cannot be implemented, because it runs contrary to the policies of each country which is to protect its own interests. Based on the background of the problem that has been described, three subject matters were identified: 1. How can the principle of non-discrimination be applied in international trade? 2. How can appropriate legal policies in dealing with the negative impact of international trade be determined? 3. How can expected disputes on international trade be resolved? The method used in this study was the normative juridical approach to literature. Studies have properties that descriptive analytical assessment phase which focuses on the assessment of secondary data. Data was collected by means of a literature study to support the object of assessment. The results of the assessment conducted revealed that the principle of non-discrimination in international trade cannot be directly applied. Although there is a variety of policies whether committed by the government or society which indirectly consider the principle of non-discrimination internationally, the principle of non-discrimination can only be applied if it can support and protect the interests of concerned parties. 
Abstrak: Perdagangan antarabangsa adalah aktiviti penjualan atau pertukaran barang / jasa di seluruh sempadan negara. Perdagangan antarabangsa sangat dipengaruhi oleh harmoni hakhak politik, undang-undang, sosial dan budaya yang dimiliki oleh negara masing-masing. Beberapa prinsip telah diformulasikan dan dikuatkuasakan untuk mencegah dan menyelesaikan pertikaian yang timbul daripada perdagangan antarabangsa, salah satunya adalah prinsip tidak diskriminasi. Kewujudan prinsip tidak diskriminasi dalam amalan sering tidak dapat dilaksanakan, kerana ia selalu bertentangan dengan dasar setiap negara untuk melindungi kepentingannya.

\section{INTRODUCTION}

Trade conducted between countries is also known as international trade. International trade can occur due to the different resources and needs owned by each country. In general, developed countries are in dire need of natural resources and labor from developing countries, while developing countries desperately need industrial products and professional services from developed countries.

Basically, international trade relations between countries have existed for a long time. These relations have come into being since the existence of states in the sense of nationalist states, the early forms of states in the modern sense. The struggle of countries to gain independence and control over the international economy forced these countries to establish trade relations with other countries.

In the history of international trade there is free trade between countries in the world. In principle, free trade is expected to provide the best solution and justice for the world's wheels of the economy. International trade arises from a mutual need to maintain the balance between politics and the economy in order to meet the interests of each country. From another point of view there is a weak side in the concept of free trade without clear controls and trade regulations. Consequently every country strives to protect itself for its own benefit.

To prevent disputes in international trade, the international community jointly establishes a principle, system and legal order in the field of international trade. The international community's awareness of regulatory needs and facilities in supporting international trade can 
be seen from the existence of some investment code instruments and conventions, international declarations up to the setting up of a resolution which has been facilitated by the World Bank, Organization for Economic Cooperation and Development (OECD), United Nations Conference on Trade and Development (UNTACD), and the World Trade Organization and General Agreement on Tariffs and Trade (WTO-GATT).

WTO has five basic principles of GATT / WTO in its development. That is:

\section{The same treatment for all members-Most-Favored-Nation Treatment (MFN)}

This principle is set out in Article I of the GATT 1994 which requires that all commitment made or signed in the framework of the GATTWHO should treat all WTO members equally (the principle of non-discrimination) and unconditionally. For example, a country is allowed to apply different rates to the level of a country compared to other countries.

On the basis of the MFN principle, member states cannot simply discriminate against their trading partners. The desire for rates of imported goods granted on a country's products should be given to imported products from trading partners of other member countries.

\section{2. $\quad$ Tariff binding}

This principle is set out in Article II of GATT 1994, where each member state of the GATT or the WTO should have a list of products that the level of import duties or tariffs should be tied (legally binding). The binding of these tariffs is intended to create "predictability" in international trade/export business affairs. This means that a member country is not allowed to arbitrarily change or increase tariff rates.

\section{National treatment}

This principle is set forth in Article III of GATT 1994 which requires that a country is not allowed to treat discriminately between imported and domestic products (the same product) in order to have protection. Types of measures prohibited under the provision in the domestic area include: the laws, regulations and requirements affecting the sale, offer for sale, purchase, transportation, distribution or use of the product, which requires the setting of the amount of the mixture, 
processing or use of the product in the country. Member countries are required to provide equal treatment for imported and local goods, at least after the imported goods enter the domestic market.

\section{Protection only through tariffs}

This principle is set out in Article XI of GATT 1994 and requires that protection of domestic industries be permitted only through tariffs.

\section{Special and Differential Treatment (S\&D) for developing countries}

To increase the participation of developing countries in international trade negotiations, S\&D is set to be one of the GATT / WTO principles. Thus, WTO agreements have provisions governing the special and differential treatment for developing countries. This is intended to provide convenience for developing member countries of WTO to implement WTO approval.

In practice, there are various principles in international trade that have the same objective of creating international trade harmonization, in addition to preventing and resolving disputes in the field of international trade. One of the fundamental principles in international trade is the principle of non-discrimination because the destination country by using various valid reasons may give different treatment to the countries of origin.

There are two main principles of non-discrimination in international trade, namely Most-Favored-Nation Principle (principle of MFN) and the National Treatment principle. The MFN principle is a requirement that the destination country treats producers of a home country, similar to the treatment they give to producers from other countries of origin, while the National Treatment principle is the principle that requires the destination country to treat foreign producers and producers in the same country just as they treat the producers of their country ${ }^{1}$. In principle, both the country of origin and the country of destination for trade have the same obligation to regulate international trade activity. Free trade is defined as not having artificial obstacles (obstacles applied by the government) in trade between individuals or companies located in different countries. Free trade is another way to develop domestic and foreign markets

See Article 1 and Article 3 of GATT. See Also: Munir Fuady. (2008) Pengantar Hukum Bisnis: Menata Bisnis Modern di Era Global, Citra Aditya Bakti, Bandung, Page. 309. 
to overcome obstacles to international trade. By opening the faucet of free trade between countries it is then possible that the economy of a country will improve with increasing exports of products.

Basically free trade allows a country to market its own products to other countries without having to go through a bureaucratic process that is convoluted, and without any additional cost on import duty of goods that must be charged based on the theory of competitive advantage.

There are problems in practice, as international trade which has now been opened freely and extensively cannot be applied to the principle of non-discrimination, such as the principle of MFN or National Treatment principle which has been a fundamental value in international trade activities. This is because countries that are the destinations of trade always discriminate to protect the production and consumption sector of their respective countries.

The discriminatory treatment between foreign and domestic products is not only practised by developing countries, but also by developed countries selling the products. Each country undertakes various policies to restrict imports of products and instead increase exports of local products as a source of income for the country.

Based on the background of the problem that has been described, the author intends to examine the principle of non-discrimination in the process of international trade. Various government policies and associations within destination countries are the main focus in assessing the effectiveness of the principle of non-discrimination as practised by these countries in conducting international trade.

\section{Identification of problems}

Based on the background of the problem that has been described, three subject matters were identified as follows:

1. How can the principle of non-discrimination be applied in international trade?

2. How can appropriate legal policies in dealing with the negative impact of international trade be determined? 
3. How can expected disputes on International trade be resolved?

\section{THE ORETICAL REVIEW AND THE POLITICAL JURIDIS OF LAW IN THE FRAME WORK OF THE IMPLEMENTATION OF INTERNATIONAL TRADE PRINCIPLES}

\section{Legal Framework in International Trade Conception}

In essence, various principles and institutions created in international trade activities are aimed at improving the living standard of human beings by increasing employment opportunities, increasing the utilization of world natural wealth, in addition to increasing the production and sale of goods and services. The existence of international laws has an important role in providing protection to producers and consumers in every aspect of international trade.

The existence of WTO / GATT in international trade is a very important form of international agreement, because WTO / GATT is an international agreement established to address potential gaps among the international community. The WTO / GATT aims to promote open cross-border trade and the reduction of barriers, both tariffs and non-tariffs.

For instance, Indonesia's participation in international trade is manifested in the form of Indonesia's participation in WTO / GATT and by establishing Law no. 7 of 1994 on Ratification of Agreement on Establishing the World Trade Organization. Indonesia has also established Law no. 7 of 2014 on Trade which expressly recognizes international trade as a form of foreign trade.

Article 1 paragraph (1) and (2) of Law no. 7 of 2014 explains that trade is an arrangement of activities related to transactions of goods and/or services within the country (domestic trade) and beyond the territory of the country (international trade/international) with the purpose of transferring the right to goods and/or services to earn rewards or compensation. Domestic trade itself is defined as trade in goods and/or services, within the territory of Indonesia which does not belong to foreign trade, whereas foreign trade is a trade which includes export and/or import activities on goods and/or trade in services that extends beyond the territory of the country. 
In international trade related to investment, the WTO has established Trade Related Investment Measures or TRIMs in the Uruguay Round negotiations. The formation of TRIMs is due to the concerns of producers and foreign investors from developed countries on the increasing number of trade and investment policies in developing countries as the destination countries of trade.

The establishment of TRIMs is intended to support recipient countries in regulating and controlling the flow of goods and services coming from foreign producers and capital inflows derived from foreign investment processes, so as to meet development objectives in the recipient country ${ }^{2}$.

The presence of TRIMs is crucial in helping to determine trade and investment master policies (especially developing countries), as TRIMs can be a means for developing countries to support the development process, in addition TRIMs can be used as a means of preventing negative impacts from international trade ${ }^{3}$.

In general, the destination country has various policies to prevent, and control foreign trade and investment, such as: policies to restrict the types of international trade and investment, politically, economically and socially.

In essence, foreign producers and foreign investors shall be allowed to enter freely to engage in legitimate activity in the destination country, despite the imposition of restrictions which is the sovereign right of the destination country to restrict certain activities of the public sector or its national property ${ }^{4}$.

According to Keith S. Rosenn, there are several aspects that must inspire the principles of international trade related to investment activities, such as ${ }^{5}$ :

1. Aspect of investor's entry permit in conducting foreign investments;

$2 \quad$ Huala Adolf. (2004).Perjanjian Penanaman Modal Dalam Hukum Perdagangan Internasional (WTO), PT Raja Grafindo Persada, Jakarta,

3 Huala Adolf, ibid.

$4 \quad$ Keith S Rosenn, CAER.(26 April 1998). "Suggested principles for Regulating Foreign Direct investment", CAER (Consulting Assistance on Economic Reform) II, Discussion Paper number.,

5 Keith S Rosenn, CAER. ibid. 
2. Aspects of information and fair notices on the rules in making investments;

3. Aspects of treatment of foreign investors;

4. Aspects of concessions or conveniences that investors can perceive;

5. Aspects about the flow of funds and transactions;

6. Aspects of provisions relating to expropriation, investor rights (nationalization);

7. Aspects of dispute resolution methods that occur.

Reviewing of the principles of international trade is associated with three (3) categories of the Theory of Justice described by Frank J Garcia, namely: utilitarian, libertarian and egalitarian.

It is utilitarian when applied to the justice of international trade law which can be described as follows:

1. Morality is required when state action brings a utility, and the state acts to maximize the utility.

2. State action through international trade law affects human utility or by reducing the welfare necessary for the satisfaction that becomes the preference or that should be put forward.

3. As such, the state is obliged in international trade law to maximize utility.

Utilitarians argue for free trade as benefit maximization or maximizing utility. The core commitment of the international legal system to free trade naturally reflects the principles of economics; the trade in which liberalization contributes to the improvement of welfare, and efficiency. Therefore it is not surprising that dominance of the normative aspects of trade law is a true utilitarian form.

Libertarians hold free trade as economic liberty, whose free trade commitment is understood as a direct consequence of a commitment to individual freedom. Government intervention in trade through tariffs and non-tariffs actually violates the principle of liberal justice because it reduces individual economic freedom. Protectionist policies are unjust because they are unilateral or non-conse- sive, by transferring the welfare of the consumer community to a group of producers. Protectionist policies are also considered illiberal because they restrict individuals in the fulfillment of the principle of freedom of contract.

The Egalitarian Theory states that free trade should be constructed in justice as fairness. The culpability of the previous theory of utilitarian and libertarian is the rationality which rejects the element 
of teleological justification and the inclusion of the principle of distributive justice based on the contractualities described by Kant. According to egalitarianism, free trade is the right policy, not because it increases welfare and not simply because it recognizes individual freedom.

It can be further explained as follows ${ }^{6}$ :

1. Fair international trade law must be formulated in such a way as to protect the moral equality of all individuals affected by it. This includes a commitment to free trade as an economic principle to maintain a liberal prerequisite for justice;

2. The liberal theory of fair trade presupposes that international trade law must operate in such a way as to benefit the least advantaged countries, thereby underlining the importance of special and differential treatment as justification for international trade law, so that each party gets the same playing field;

3. Liberal justice presupposes that international trade law does not sacrifice human rights and the effective protection of human rights in the context of the achievement of profit.

The existence of the Theory of Justice in international trade acts to avoid conflicts including institutional and doctrinal conflicts; to restore the circumstances resulting from failures in the implementation of free trade as well as to emphasize the liberal moral obligations that must be applied equally both to the rules governing domestic relations and to international trade relations governing transactions with foreign trading partners ${ }^{7}$.

\section{Political Law in Determining International Trade Policy}

Prior to establishing trade cooperation between countries and in accordance with the development process it is most important to determine the political direction of the law to create a proper regulation in the face of all the impacts of international trade. In

6 Frank J Garcia.(2003) Trade, Inequality, and Justice: Toward a Liberal Theory of Just Trade, Transnational Publishers. New York. Page 72.

7 Sylviana Kusuma Lestari.(2010). Tinjauan Yuridis Atas Perlindungan Hukum Terhadap Industri Dalam Negeri Melalui Peraturan Nasional Dikaitkan Dengan Upaya Safeguards, master's degree thesis in University of Indonesia, Jakarta, Page. 10. 
determining the legal politics to establish the right legal basis can set the direction of development so that it is in accordance with the development planning program.

According to Satjipto Rahardjo, "law can be classified into a driving factor that can provide the first systematic impulse in line with expectations"8. This is in line with the view of Mochtar Kusumaatmadja, that the law is a tool of development, namely law in the sense of rules or rules of law that functioned as a tool or means governing development in the sense of channeling the direction of human activity in the direction desired by development or renewal' .

Mochtar Kusumaatmadja explains that the law is not only a set of rules and principles governing human relations in society, but must include the institutions and processes necessary to realize the law in reality ${ }^{10}$.

When establishing the politics oflaw in determining economic policies in international trade, it cannot be separated from the conception of the economic analysis of law, one of which is described in Jeremy Bentham's utilitarian conception that systematically examines how people deal with legal incentives and evaluate the results according to measures of social welfare ${ }^{11}$.

According to Cheryl W Gray, there is a prerequisite for a legal system to function well in a market economy ${ }^{12}$ :

1. The availability of market-friendly laws;

2. The existence of an institution capable of effectively implementing and enforcing the relevant law; and

3. There is a need of market participants for the law and legislation.

Philosophically, it means that domestic trade has no difference with international trade. Domestic and international trades are both based

Satjipto Rahardjo, Ilmu Hukum, Citra Aditya Bakti, Bandung, Page 209.

9 Mochtar Kusumaatmadja. (2002).Konsep-konsep Hukum dalam Pembangunan, Alumni, Bandung, Page 88.

10 Mochtar Kusumaatmadja. (1976). Hukum, Masyarakat dan Pembinaan Hukum Nasional, Bina Cipta, Bandung, Page 15.

11 Louis Kaplow and Steven Shavell. (1999). Economic Analysis of Law, National Bureau of Economic Research, Cambridge, Page 1.

12 Cheryl W Gray. (1999). "Reforming Legal Systems in Developing and Transition Countries" (Reformasi Hukum Di Negara Sedang Berkembang, Jurnal Hukum Bisnis, Vol. 6. Jakarta 
on an agreement to conduct sale and purchase, and transactions or exchange goods/services to meet the needs of each party. The difference between domestic and international trade is only in the form of export/import marketing, technicalities of export/import financing, trade insurance, shipping and customs aspects.

Regulatory requirements, whether arrangements made by the country of origin or destination country in international trading activities are more due to several reasons including the following ${ }^{13}$ :

1. Buyers and sellers are separated by state boundaries.

2. Goods are sent from one country to another through various regulations, such as customs regulations issued by each country.

3. There are differences in language, currency, measures and scales, laws and regulations in trade between one country and another, and so on.

According to Chen, Edward K. Y, there are stages and types of international trade policies related to investment in the field of industrialization, such as ${ }^{14}$ :

1. Import Substitution 1 (IS 1), Produce consumer goods, using protectionist measures to groom infant industries;

2. Import substitution 2 (IS2), Produce capital goods and consumer durables;

3. Export Orientation 1 (EO1) Produce labor-intensive light manufactured goods;

4. Export Orientation 2(EO 2) and Export Orientation 2 Complex (EO2- complex), Produce technology/capital/knowledgeintensive industries, developing services, especially financial, undergoing technological and economic restructuring.

The problem of the lack of interest in foreign producers is actually a barrier to creating a market friendly legal system in developing countries, such as the establishment of law in developing countries which face the problem of simultaneously implementing the three

13 Amir MS. (2000). Seluk Beluk dan Teknik Perdagangan Luar Negeri, Penerbit PPM. Jakarta.

14 Chen, Edward K.Y. (1988/1997).The Economics and Non Economics of Asia's Four Little Dragons (The Asia Model of Economic Development: Policy Implication For The 21st Century"), Institute Of Developing Economies", Tokyo. 
stages of legal development related to the politics of the countries passed - modern industrial countries, namely the unification stage, the industrialization stage and the social welfare stage ${ }^{15}$.

As for the obstacles in carrying out these three stages by developing countries, this can be further explained as follows ${ }^{16}$ :

1. Problems that occur at the stage of unification, is the issue of political integration of a society or the formation of a unitary state.

2. Problems that occur at the stage of industrialization, is the problem of economic and political modernization struggle, and in this stage the government is required to serve as a driver of growth of new elites, such as industry professionals and promote the principles of capital accumulation.

3. Problems at the social welfare stage, is a problem related to the shift in the role of the government to become the protector of society from the hardness of industrial life by scheduling welfare programs.

\section{APPLICATION OF INTERNATIONAL TRADE PRINCIPLES IN DETERMINING LEGAL POLITICS IN INDONESIA}

\section{Domestic Protection to Prevent Negative Impacts and to Improve Positive Impacts of International Trade}

International trade is philosophically a form of trade based on mutual need among different countries. The need for international trade is not only related to the government as the ruler of the state, it is carried out by individuals, legal entities and communities that cross national borders. Therefore, international trade is not only the domain of the government, but all parties involved in international trade activities.

\footnotetext{
15 Thomas M Franck. (1972).The New Development: Can American Law and Legal Institutions Help Developing Countries?, Wisconsin Law Review No.3, Page 771-778.

16 The third stage is an approach first proposed by Thomas M Franck and Organski. (1970). Ibid; See also: Wallace Mendelson, Law and the Development of Nations, The Journal of Politics vol. 32 Page 224-225.
} 
In essence, the principles created and established in the various theories of international trade are aimed at creating harmony between the country(s) of origin and the destination country(s) of international trade. The principles that are created and established in international trade should be able to contribute positively to each country to conduct international trade in a controlled manner which can further provide mutual prosperity.

Philosophically, the principle of non-discrimination is a fundamental principle in international trade, but the principle of non-discrimination is not obviously applicable in practice. This is because each country has its own interests and sovereignty in exploiting international trade without disturbing the interests of the domestic economic sector.

The principle of non-discrimination is also inapplicable, as each country (especially developing countries) has concerns that international trade entering the country can have a direct or indirect negative impact on domestic interests.

Discriminatory treatment between destination countries and countries of origin concerning domestic interest is unavoidable. Discrimination is not only practised by the government as the ruler of the state, but it is also exercised by associations engaged in the economic sectors of the society.

Some policies explain that the non-discriminatory principle cannot be applied effectively. This can be seen from different tax policies between imported and domestic products and the determination of certain quotas on only certain type of imported products.

In the field of the labor profession as a form of international trade in services, the principle of non-discrimination can also be seen from the different treatment between foreign and domestic workers. One form of non-discrimination principle cannot be applied. This can be seen from Article 3, paragraph (1) and (2) of Law no. 18 of 2003 on Advocates which requires the profession of advocate as an Indonesian citizen and residing in Indonesia.

Government policies to support international trade and foreign investment are based on internationally recognized principles, although in practice the principles of international trade cannot be 
effectively applied, in addition to principles in international trade, intends to destination country (the country receiving goods and services).

Various inequalities in the application of the principles prevailing in international trade between developed and developing countries have led to many problems especially for the developing countries. Therefore in practice the application of uncontrolled international trade principles can lead to various problems in a country which disrupts national interests. Nevertheless, every state and government has formulated a policy and law based on general principles applicable to international trade.

\section{Determining Policy Formulation to Prevent Negative Impacts and to Improve Positive Impacts in Facing International Trade}

International trade as a form of activity and process always has two (2) impacts, namely positive and negative impacts; that each impact can be controlled by determining the right policy and regulatory direction in the face of an increasingly dynamic international trade.

The positive impacts and negative impacts caused by international trade are as follows:

\section{Positive Impacts of International Trade:}

a. Fulfills domestic needs that previously could not be fulfilled. It can foster closer relations between nations in the world, and the fulfillment of domestic needs that previously could not be fulfilled.

b. Improves competitiveness and quality of domestic goods/services to benefit consumers and improve the creativity of domestic products so as to continue to grow and innovate in order to thrive in the country.

c. Increases revenue and foreign exchange including countries that rely on their foreign exchange import duties.

d. Science and technology transfers that can support the development process when previously it was only for domestic consumption, now it can meet domestic and foreign needs. 
e. Improves and grows business sectors of society to meet domestic and foreign needs by familiarizing domestic products in other countries and vice versa, so that local consumers need not have to go abroad to get products from another country.

f. Fosters the economic growth of a country, and the equity of the people's welfare.

g. The presence of products from another country will create a new inspiration for producers in the country.

h. Increases new job opportunities.

\section{Negative Impacts of International Trade:}

a. There is also free competition among producers from different countries, and as the process described earlier the market mechanism will eliminate producers from non-competitive countries. Due to differences in the quality of human resources, the availability of production factors, the mastery of technology and infrastructure (which developed countries have a head start) the cost of production in developing countries will be higher as their producers will produce goods at a relatively more expensive price than the price of goods from developed countries. In this competition the producers of developing countries will lose, their markets will be seized, their business liquidated and their workers will lose jobs.

b. Increases domestic unemployment and Indonesian labor (TKI) abroad as domestic companies are unable to compete.

c. Improves consumer culture societies, because people prefer to buy rather than produce goods/services.

d. Political, economic, social and cultural pressures emerge as foreign countries have a dominant position in international trade.

e. Increased risk of disputes between countries, both the government itself and the general public who conduct international trade. This can result in dependence on goods produced by other countries.

g. There could be unhealthy competition between importing countries. 
h. Trade related problems between countries.

i. When there is a redistribution of income and employment because of free competition, the developed countries will reap the rewards due to increase in productivity while the producers of developing countries will only get 'leftover' jobs to produce low-tech goods with low margins. Consequently, their workers will end up with second-class jobs, which require relatively less skills and knowledge, more dangerous perhaps and certainly lower rewards. Developing countries are only used by the market for its cheap labor and raw materials which will also be dredged up reflecting an unfavorable redistribution of employment and income for these countries.

The positive impact derived from international trade is the hope of every world society to enhance mutual prosperity. However, the negative impact of international trade should be prevented and avoided by establishing the following policies and regulations:

1. Determine quality standards on imported and domestic goods/ services;

2. Determine the quota of imported and domestic goods/services so as to meet domestic needs without causing depreciation in prices;

3. Improve the quality and quantity of potential domestic goods/ services to meet domestic needs;

4. Impose restrictions on unproductive imported goods/ services;

5. Transform cultures from a culture of consumerism (import) to one of entrepreneurship (export).

Assessment of the various principles prevailing in international trade linked to various policies must be taken to prevent the negative impact of international trade. Assessment can be conducted through Posner's conception which eliminates the legal doctrinal nature, since the law cannot be applied using only the normative approach, but requires a variety of approaches, such as economic approach (A number of scholars believe that interpretation is the path to saving the law's objectivity) ${ }^{17}$.

17 Richard A. Posner.(1998). Economic Analysis of Law, Boston: Little Brown, 1998, Page. 3-10. See Also: Richard A. Posner, "Rational Choice, Behavioral Economics, and the Law," Stanford law Review, Vol. 50. Page. 1552-1554. 
Principles in international trade can contribute positively to the determination of a country's policy on condition that the principles of international trade can actually contribute positively to the interests of that country.

Any losses and gains as a result of international trade are characteristics that are always found in a process. Any impact resulting from international trade should be addressed by determining an appropriate policy(s) taking into account the principles of international trade as the legal basis for formulating an international trade policy(s). Accountability due to the negative effects of international trade in principle may be borne by any person directly involved in and contributing to such international trade, whether acts committed by the government, legal entities, individuals or international organizations.

Safeguard measures should be considered in formulating policies as it is one of the trading policy instruments similar to anti-dumping and anti-subsidy policies. All three policies are similarly regulated in the WTO, and both may be subject to additional import duty if they cause injury to the importing state.

According to Regulations of the Minister of Trade No. 37 / M-Dag / Per / 9/2008 safeguard actions taken by the government to recover serious losses or prevent the threat of serious industrial losses as a result of increasing imports of similar products or goods directly competing with domestic industrial products with the objective of making domestic industries suffer serious losses or threats of serious harm can be made through structural adjustments.

The legitimate safeguards are as follows:

1. The action must be performed by the government.

The government takes measures to secure its local industry from serious harm or serious threat of harm caused by the abundance of imported products entering Indonesia. In this case the government plays the role of policy maker and acts to safeguard the domestic industry, not the direct business actors involved in carrying out such security measures. 
2. There is a serious loss or threat of serious harm.

The intention of serious harm here is the real loss suffered by domestic industries. While the meaning of the threat of serious harm is the threat of serious losses that will be suffered in the near future by the domestic industries resulting from increasing imports of products from another country(s). The objective of such measures is to protect or restore the domestic industries.

3. Similar goods are domestically produced goods that are identical or identical in all aspects with the goods being investigated or goods having physical, technical, or chemical characteristics resembling the intended merchandise.

4. There are goods that directly compete.

Goods that directly compete are goods of domestic production which are similar to or are substitutes of investigated goods.

The safeguard arrangement refers to Article XIX GATT as enhanced by the Agreement on Safeguard 1994. Safeguard measures are also regulated in the Indonesian legal system, namely Presidential Decree No. 84/2002 concerning the Safeguard Measures of Domestic Industries from Duplication Import Surge and Regulation of the Minister of Trade No. 37 of 2008 concerning Certificate of Origin on Imported Goods Subject to Safeguard Measures.

\section{International trade disputes settlement}

The involvement of developing countries in the WTO's litigation process is a manifestation of a desire to make a breakthrough from the difficulties that cripple these countries in the face of its more advanced trading partners. Apart from the diplomatic process, GATT throughout history has failed to produce the expected results even more so by inviting unilateral practices which are destructive by developed countries or through bilateral pressures by hiding under the protection of WTO laws that are believed to provide justice to them in international trade. According to Davis ${ }^{18}$ there are four rules of law that can help developing countries to counteract

Cristina. L. Davis. Do WTO Rules Create A 'Level Playing Field? Lesson From the Experience of Peru and Vietnam,>princeton.edu/-cl davis/files/davis. 
the discriminatory practices, One of the rules is the choice to file a lawsuit that gives power to a developing country that can force developed countries to come to the negotiating table to discuss their request. Another rule of settlement in the WTO is the DSU (Dispute Settlement Understanding) which becomes international trade law as a reference for reaching agreement. A further rule is using a common agreement which allows developing countries to gain allies to support their case. Another rule is that long-term economic interest to support the rule encourages compliance with the rule of rules. As stated by Davis, bringing rich trading partners to the negotiating table to discuss protectionist trade barriers makes it a difficult job for developing countries ${ }^{19}$.

The lawsuit of Venezuela as a developing country against a USrich country in a case known as the 'US Standard for Reformulated and Conventional Gasoline' of the first lawsuit proceeded to the panel level and even up to the Appellate Body. In this case ${ }^{20}$ Venezuela sued the US policy because the policy created by the US Environmental Protection Agency impacted the gasoline from Venezuela, which prompted Venezuela to establish a panel after the failure of bilateral consultations between the two countries. Then Brazil joined the Venezuelan side in a panel report submitted to the settlement agency. The WTO's Dispute Settlement Body (DSB) stated that the US policy contradicted the provisions of Article III paragraph 2 (national treatment) GATT 1994, also Article XX (b), (d), and (g). The panel recommended for the DSB to request the US to change certain parts of the Gasoline Rule which was in line with the obligations of the General Agreement. The panel emphasized that every WTO member is free to set up its own environmental policy targets, but they are bound to implement these objectives in a manner consistent with the General Agreement, especially those concerning the treatment of products for domestic consumption and import. The US alone stated that the country would appeal to question a number of legal interpretations made by the panel. In accordance with the applicable procedures on the panel report, it was not acceptable because one party appealed to the Appellate

\footnotetext{
19 Ibid

20 Peter Van den Bossche. (28-29 November 2003). The Doha Development Round Negotiations on the Dispute Settlement Understanding, WTO Conference. New Agenda in the $21^{\text {st }}$ Century, Taipei.
} 
Body. This was the first time the institution in this intercity trade settlement system would function. Furthermore, the Appeals Institute which examined the panel's interpretation of article XX GATT had made improvements, essentially retaining the panel's conclusions. Cases involving developing countries are evidence that developing countries have the confidence that a dispute resolution system under the WTO provides hope to them that their trade interests as weak states will be protected.

A total of 302 disputes were submitted by its members within eight years after the WTO was formed for the WTO to settle under the multilateral DSU rules. No doubt in comparison to the rarely used GATT dispute resolution system, the WTO dispute resolution system is the most commonly used system by developing country participants especially those who have resolved their trade disputes at the WTO. Although developing countries play a more active role in the WTO dispute process than in the GATT 1947 period, there are still serious problems that must be overcome - the costly cost of persuasion in the WTO is a common denominator of a developing country. A source estimates the costs to be levied in the WTO litigation process as follows: A conservative estimate of the tariff of an international trade lawyer is USD $350 / \mathrm{hr}$ thus legal services can range from USD 89,950 to USD 247. 000 fee in9i. This is excluding the cost of expenses incurred from litigation support costs such as collecting data, economic analysis and the additional cost if using expert witnesses which can reach up to USD 100 to USD 200 not to mention the cost of travel, accommodation, legal and secretariat fees so much so that the cost of litigation could go up to USD 500,000 which is common to an exporter seeking to gain market access.

\section{CONCLUSION}

1. The principle of non-discrimination may be applied in international trade as long as it is not contrary to the interests of a country. Its principle has caused some concern with regards to the weakening of the domestic economic sector. However, the public should not be worried about the arrival of imported products as maintaining the quality and price of domestic products which can compete with imported ones are more important besides knowing more about the needs of local consumers in every region in the country. 
2. Appropriate legal politics need to be in place to deal with the negative and positive impact of international trade by considering the principles of international trade and the domestic interests of a country and that it should be based on juridical and non-juridical considerations.

3. The WTO trade dispute resolution seems to recognize that the system has been of considerable benefit to its users, including among developing countries in reducing and removing barriers to trade and expanding market access.

\section{Suggestions}

1. Since the principle of non-discrimination is not always applicable and integrated in a policy, countries involved in international trade should be aware of some of the discriminatory policies still in existence in international trade.

2. Considering that appropriate policies to prevent the negative effects of international trade are essential, policy formulations should always take into account juridical as well as nonjuridical aspects.

3. It is more cost-effective to settle disputes through the WTO so that developing countries can benefit from this institution.

\section{REFERENCES}

Amir, MS. (2000). Seluk beluk dan teknik perdagangan luar negeri. Jakarta: Penerbit PPM.

Chen, E. K.Y. (1988/1997).The economics and non economics of Asia's four little dragons (The Asia Model of Economic Development: Policy Implication for the 21st Century). Tokyo: Institute of Developing Economies.

Cheryl, W. (1999). Reforming legal systems in developing and transition countries (Reformasi hukum di negara sedang berkembang. Jurnal Hukum Bisnis, 6, Jakarta.

Frank, J. (2003). Trade, inequality, and justice: Toward a liberal theory of just trade. New York: Transnational Publishers.

Huala, Adolf. (2004). Perjanjian Penanaman Modal Dalam Hukum Perdagangan Internasional (WTO), PT Raja Grafindo Persada, Jakarta. 
Keith, S. R. CAER. (1998). Suggested principles for Regulating Foreign Direct investment, CAER (Consulting Assistance on Economic Reform) II, Discussion Paper no., 26, April 1998.

Louis. K., \& Steven, S. (1999). Economic Analysis of Law, National Bureau of Economic Research, Cambridge.

Mochtar, K. (1976). Hukum, masyarakat dan pembinaan hukum nasional. Bandung: Bina Cipta.

Mochtar, K. (2002). Konsep-konsep hukum dalam pembangunan. Bandung: Alumni.

Munir, F. (2008). Pengantar hukum bisnis: Menata bisnis modern di era global. Bandung: Citra Aditya Bakti.

Richard, A. (1998). Economic analysis of law. Boston: Little Brown.

Richard, A. P. (1998). Rational choice, behavioral economics, and the law. Stanford law Review, 50.

Satjipto Rahardjo. (1991). Ilmu hukum. Bandung: Citra Aditya Bakti.

Sylviana, K. L. (2010). Tinjauan Yuridis Atas Perlindungan Hukum Terhadap Industri Dalam Negeri Melalui Peraturan Nasional Dikaitkan Dengan Upaya Safeguards, (thesis pasca sarjana Universitas Indonesia), Jakarta.

Thomas, M. (1972). The new development: Can American law and legal institutions help developing countries? Wisconsin Law Review, 3.

Wallace, M. (1970). Law and the development of nations. The Journal of Politics, 32. 